ministry.

There is also a plan to promote the mobility of students between universities by means of a system of credits, while the standard pattern of the five-year degree course to which Polish universities have been traditionally wedded will be loosened by the new law on degrees. There will be a four-year course leading to a batchelor's degree alongside the traditional five-year course that wins an engineering qualification.

But the details of the new pattern remain to be decided. Roman says "we are going to join Europe now", which is why the university is closely following developments in the West, with the objective of matching its own pattern with that of institutions further to the West.

That will not be easy. Despite its high reputation, the polytechnic university has had a recruitment problem. The student body has declined from 20,000 to about 13,000 now. (The result is a generous staff: student ratio of 1:5.) But Roman is looking for a 15 per cent increase in the year ahead, as well as an increase of the numbers of students from elsewhere in Europe.

There are also problems in research. Polish universities have been luckier than those elsewhere in Europe in retaining research interests, but the shortage of equipment - especially by comparison with Western Europe - is now crippling, even inhibiting of researchers' ambitions. For the short term, Roman pins his faith on collaborative agreements with universities in the West. He is especially pleased with a recent understanding with the Fachhochschule at Cologne, under the terms of which the German university will be sending doctoral students to Warsaw.

In the present climate, the university is optimistic, the erosion of academics' salaries by inflation notwithstanding. The political transformation of Poland will not make waves comparable with those of the university's chequered past. Originally founded in 1826 , the polytechnic was closed for 60 years until reopened as a Russian institution in 1898 - and solemnly boycotted by Poles until the end of Russian domination in 1915.

J.M.

\section{Waiting for the dust to settle}

Warsaw

THE Polish Academy of Sciences, abbreviated PAN (where the ' $N$ ' means nauki, the Slav word for 'science'), has a new president, historian Alexander Gieysztor, who is as often to be found at the splendidly refurbished Royal Castle in the old city as at PAN's headquarters in the downtown Palace of Culture and Science.

Poland also has a kind of alternative to the official Academy, a group of 150 people organized by Professor Andrzej Ziabicki, from PAN's Institute of Fundamental Problems in Technology, which reckons to keep a watchful and sceptical eye on the process of reform. The group has been arguing that the true Academy should separate its three distinct functions as academy proper, as adviser to government and as manager of in-house research.

Gieysztor's position is straightforward - the Academy needs to be autonomous. (Here, as elsewhere, the government has held senior appointments in its gift.) Part of his objective is to give Academy institutes shop-floor democracy and to remove their control from the government-appointed secretary-general.

He sees many changes in the months ahead. Two institutes (for Socialist Countries and for Political Science) have already been abolished. Maybe there is now a need for an Institute of European Studies some institutes, on the other hand, may have to merge with university departments. The PAN Institute of Lexicography might be such a case.

But Gieysztor does not wish to see PAN lose its responsibility for research. (He says that institute directors were asked, on 17 March, whether they would favour such a change, but that they elected to stay within the academy.) In general, he is anxious that the academy's institutes should have legal independence, and that it should be possible for many of them to earn funds from other sources than the general subvention from the academy.

Giesyztor is less cheeful about Poland's future in research than many other people. Over the years, he says, the country has lost "many thousands" of talented people. And more recently, the scientific enterprise has suffered from having had an "antiintellectual government". There are serious problems in the shortage of funds, the lack of equipment and periodicals and the poor development of computer services in Poland.

More than that, there is the difficulty that forty years of the previous regime have conditioned people to the "omnipresence of the state in private as well as public life". How, in those circumstances, will it be possible to create a market economy quickly? John Maddox spending on research will be the only means of ensuring that research and development continues, but continuation will depend crucially on what the governThere may be hard times ahead. In the past few years, the government reckons ment has exceeded 3 per cent of national directly comparable with those current in the West because of the different way in (The informal private sector is left out of to be more than 110,000 people work versity teachers), of whom only 10 of Sciences. degrees.

the research enterprise will be under severe pressure. Quite apart from the poverty of scientists' salaries, and the ment, there will be social pressures on the government's budget that it will not be possible to resist. One of the consequences of economic reconstruction, for example, must be dreaded unemployment, which can only be made palatable not yet exist.

That is one reason why those now pinning their hopes for Polish science on a system of competitive grants may not be nearly as cheerful a few months from now, when it may turn out that there is very little money for which to compete. J.M. 